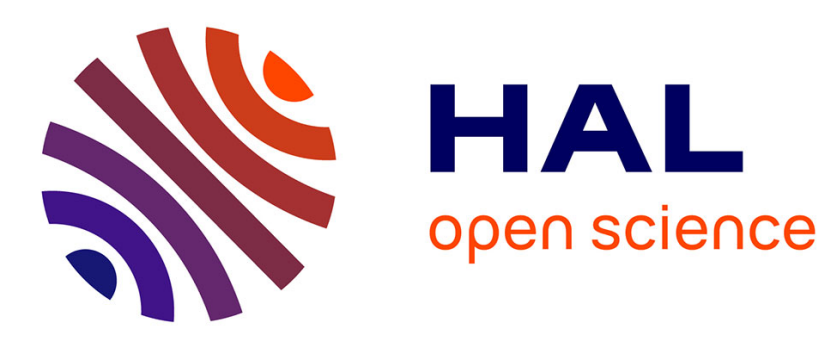

\title{
Ovariectomy and estrogen treatment modulate iron metabolism in rat adipose tissue
}

\author{
Giuseppina Mattace Raso, Carlo Irace, Emanuela Esposito, Carmen \\ Maffettone, Anna Iacono, Antonio Di Pascale, Rita Santamaria, Alfredo \\ Colonna, Rosaria Meli
}

\section{To cite this version:}

Giuseppina Mattace Raso, Carlo Irace, Emanuela Esposito, Carmen Maffettone, Anna Iacono, et al.. Ovariectomy and estrogen treatment modulate iron metabolism in rat adipose tissue. Biochemical Pharmacology, 2009, 78 (8), pp.1001. 10.1016/j.bcp.2009.05.034 . hal-00514595

\section{HAL Id: hal-00514595 \\ https://hal.science/hal-00514595}

Submitted on 3 Sep 2010

HAL is a multi-disciplinary open access archive for the deposit and dissemination of scientific research documents, whether they are published or not. The documents may come from teaching and research institutions in France or abroad, or from public or private research centers.
L'archive ouverte pluridisciplinaire HAL, est destinée au dépôt et à la diffusion de documents scientifiques de niveau recherche, publiés ou non, émanant des établissements d'enseignement et de recherche français ou étrangers, des laboratoires publics ou privés. 


\section{Accepted Manuscript}

Title: Ovariectomy and estrogen treatment modulate iron metabolism in rat adipose tissue

Authors: Giuseppina Mattace Raso, Carlo Irace, Emanuela Esposito, Carmen Maffettone, Anna Iacono, Antonio Di Pascale, Rita Santamaria, Alfredo Colonna, Rosaria Meli

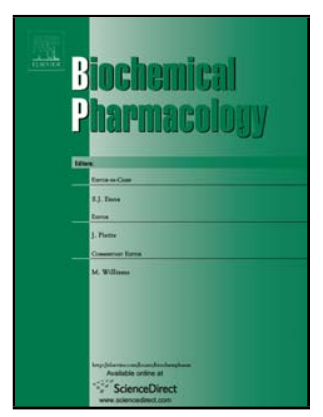

PII: S0006-2952(09)00444-4

DOI: doi:10.1016/j.bcp.2009.05.034

Reference: BCP 10205

To appear in: $\quad B C P$

Received date: 26-3-2009

Revised date: 26-5-2009

Accepted date: $\quad$ 26-5-2009

Please cite this article as: Raso GM, Irace C, Esposito E, Colonna A, Ovariectomy and estrogen treatment modulate iron metabolism in rat adipose tissue, Biochemical Pharmacology (2008), doi:10.1016/j.bcp.2009.05.034

This is a PDF file of an unedited manuscript that has been accepted for publication. As a service to our customers we are providing this early version of the manuscript. The manuscript will undergo copyediting, typesetting, and review of the resulting proof before it is published in its final form. Please note that during the production process errors may be discovered which could affect the content, and all legal disclaimers that apply to the journal pertain. 
Estrogen regulates the RNA-binding activity of the IRP1 and consequently the expression of the ferritin and transferrin receptor in adipose tissue

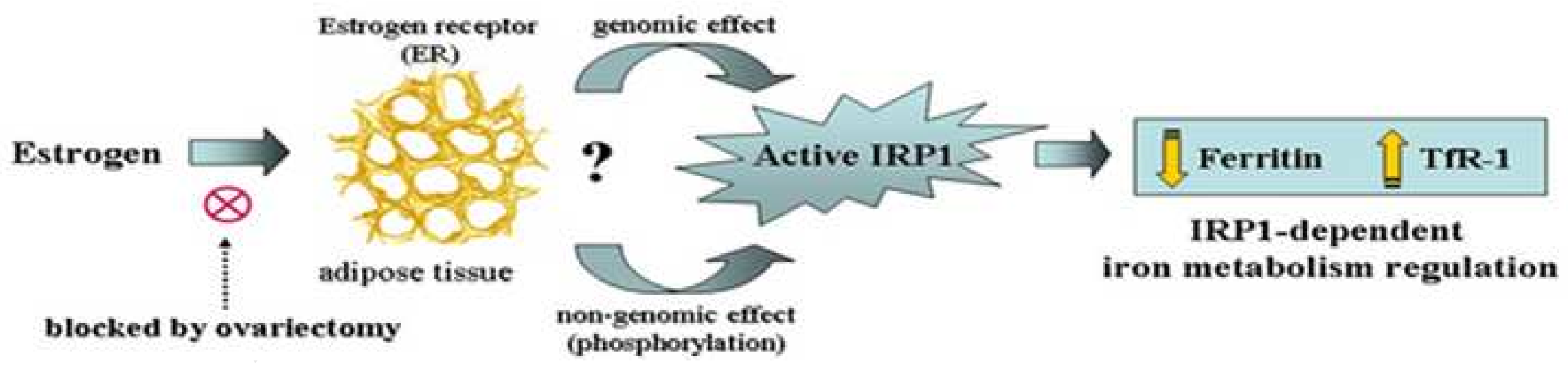




\section{Ovariectomy and estrogen treatment modulate iron metabolism in rat adipose} tissue

Giuseppina Mattace Raso ${ }^{\mathrm{a}}$, Carlo Irace ${ }^{\mathrm{a}}$, Emanuela Esposito, Carmen Maffettone, Anna Iacono Antonio Di Pascale, Rita Santamaria*, Alfredo Colonna and Rosaria Meli.

Dipartimento di Farmacologia Sperimentale, Università degli Studi di Napoli "Federico II", via D. Montesano, 49-80131 Naples, Italy.

mattace@unina.it

carlo.irace@unina.it

emaesposito@unina.it

camaffet@unina.it

annaiacono@hotmail.it

antonio.dipascale@unina.it

rsantama@unina.it

alfcolon@unina.it

meli@unina.it

${ }^{a}$ These authors contributed equally to this work.

*Corresponding author. Department of Experimental Pharmacology, via D. Montesano, 49-80131 Naples, Italy. Tel. 39-081-678421; fax 39-081-678403.

E-mail address: rsantama@unina.it (R. Santamaria). 


\section{ABSTRACT}

Iron is essential for many biological processes and its deficiency or excess is involved in pathological conditions. At cellular level, the maintenance of iron homeostasis is largely accomplished by the transferrin receptor (TfR)-1 and by ferritin, whose expression is mainly regulated post-transcriptionally by Iron Regulatory Proteins (IRPs).

This study examines the hypothesis that modification of serum estrogen levels by ovariectomy and $17 \beta$-estradiol $\left(\mathrm{E}_{2}\right)$ treatment in rats modulate serum iron-status parameters and iron metabolism in adipose tissue. In particular, we evaluated the RNA binding of IRP1 by electrophoretic mobility shift assay and IRP1, ferritin, and TfR-1 expression in adipose tissue by Western blot analysis. Ovariectomy, besides a lowered serum iron and transferrin iron binding capacity, remarkably decreased the binding activity of IRP1 in peritoneal and subcutaneous adipose tissues, and these effects were reversed by $\mathrm{E}_{2}$ treatment. Moreover, ovariectomy determined a decrease of IRP1 expression, which was significant in subcutaneous adipose tissue. Consistent with IRP1 regulation, an increase of ferritin and a decrease of TfR-1 expression were observed in peritoneal adipose tissue from ovariectomized animals, while the treatment with $\mathrm{E}_{2}$ reconstituted TfR-1 level. A similar expression profile of TfR-1 was observed in subcutaneous adipose tissue, where ferritin level did not change in ovariectomized animals, and was increased after $\mathrm{E}_{2}$ treatment.

Our results indicate that estrogen level changes can regulate the binding activity of the IRP1, and consequently ferritin and TfR-1 expression in adipose tissue, suggesting a relationship among serum and tissue iron parameters, estrogen status and adiposity.

Key words: estrogen; ovariectomy; adipose tissue; iron metabolism; iron regulatory proteins. 


\section{Introduction}

Iron requirement in vertebrates arises since it is an essential component of proteins that perform redox or non-redox roles in many critical cellular functions, including respiration and cell division. Its deficiency or excess is involved in pathological conditions, i.e. iron-deficient anemia or ironoverload, such as hemochromatosis [1]. In addition to anemia, iron deficiency impairs muscle, immune and cognitive functions [2]. Dysregulation of iron metabolism associated with hemochromatosis and other iron overload disorders is also a significant health concern [3]. Iron cytotoxicity is due to the ability by which free iron, as $\mathrm{Fe}^{2+}$ ions, participates in redox reactions, leading to the production of harmful oxygen radicals (ROS) that can damage cellular structures [4]. Consequently, to suppress the potential deleterious effects of iron, cells have evolved homeostatic mechanisms that regulate transport, storage and mobilization of this essential element.

In mammals, iron is mostly bound to various cellular components, such as haemoglobin, heme, various enzymes and ferritin, the ubiquitous intracellular iron storage protein [5]. Extracellular iron is bound to transferrin (Tf), which shuttles iron through the blood to target tissues. Mono- and diferric-transferrin bind to the Tf-receptors (TfR-1 and TfR-2), that transport iron into the cell via clathrin-coated pits [6]. At the cellular level, maintenance of iron homeostasis is largely accomplished by the TfR-1, that allows iron uptake, and by ferritin, which is crucial to sequester this metal in a non-toxic form. The levels of these and other proteins involved in iron metabolism are mainly regulated post-transcriptionally by interaction between the Iron Regulatory Proteins (IRP1 and IRP2) and stem-loop structures, termed IREs (Iron Responsive Elements), located in the 5' untranslated region (UTR) of ferritin mRNAs and in the 3' UTR of TfR mRNA [7, 8]. The IRPs provide a central role in the regulation of cellular iron homeostasis. IRP1, the cytosolic counterpart of mitochondrial aconitase [9], is a bifunctional protein that, through [4Fe-4S] cluster assembly/disassembly, switches from the aconitase to the IRP1 form mainly in response to the intracellular iron level. IRP2 is homologous to IRP1 but lacks the [4Fe-4S] cluster and its activity increases in iron-depleted cells by protein stabilization [10]. Intracellular free iron regulates IRP1, 
affecting its RNA-binding affinity, and IRP2, inducing its proteasomic degradation $[11,12]$. Specifically, when intracellular iron content decreases, IRPs interact with multiple IREs within the 3'-UTR of TfR-1 mRNA, strongly increasing mRNA half-life and TfR-1 protein expression [13]. Simultaneously, the binding of IRPs to IRE cis-element in the 5'-UTR of ferritin mRNA prevents its synthesis $[14,15]$. On the other hand, high iron levels reduce IRPs affinity to IREs (i.d. IRP1 is no longer able to bind IRE and IRP2 is degraded), resulting in rapid TfR-1 mRNA degradation and in efficient translation of ferritin [16].

The IRPs RNA-binding activity is also regulated by iron-independent factors, such as oxidative stress [17], nitric oxide signalling [18], protein phosphorylation [19], hypoxia [20,21], as well as oxalomalic acid, an inhibitor of aconitase/IRP1 [22, 23], and virus infection [24]. Among hormones, thyroid hormones regulate post-transcriptionally the synthesis of proteins involved in iron metabolism by affecting IRPs ability to bind to IRE [25]. Insulin and IGF1 have also been implicated in the regulation of ferritin at the mRNA level [26]. Estrogen hormones might also influence the expression of iron-related proteins, but the only relevant data are related to systemic iron metabolism. In fact, Haouari et al. $[27,28]$ described the effects of $17 \beta$-estradiol $\left(\mathrm{E}_{2}\right)$ on iron absorption and uptake in ovariectomized rats. In particular, they found a significant rise in iron uptake by the small intestine and a subsequent increase in serum iron level, accompanied by a decrease in total iron binding capacity (TIBC) in $\mathrm{E}_{2}$-treated ovariectomized rats. Furthermore, a correlation between $\mathrm{E}_{2}$ administration and an increase of splenic iron stores has been demonstrated in ovariectomized rats subjected to hormone therapy, showing that the amount of iron stored depends directly on circulating estrogens [29].

Besides its function as storing energy, adipose tissue secretes a variety of peptides, such as leptin and adiponectin which act in autocrine/paracrine and endocrine manner [30] and is involved in the metabolism of sex steroids, expressing enzymes for their activation, interconversion, and inactivation [31]. Although adipose tissue is not considered the main target of estrogens, its excess or obesity, particularly in the visceral compartment, is associated with insulin resistance, 
hyperglycemia, dyslipidemia, hypertension, and inflammation [32], as well as with estrogen deficiency. In turn, overweight and obesity are often related with systemic iron status: in fact iron may also be involved in the maintenance of body weight and composition [33-34]. Very little attention has been paid to the molecular mechanisms regulating iron homeostasis in adipose tissues. It has been previously reported a specific regulation of iron homeostasis, with a consistent accumulation of ferritin, in mature adipocytes [35].

Here, we evaluated the iron-status parameters, and the activity and expression of the main proteins of iron metabolism in adipose tissues from estrogen deficient rats ( 7 weeks after ovariectomy) and after estrogen treatment by $\mathrm{E}_{2}$. Seven-week ovariectomy induced in rats a mild obesity that mimics estrogen insufficiency in human [36] and creates a useful in vivo experimental model of hypoestrogenism. 


\section{Material and methods}

\subsection{Animals and treatments}

Female Sprague Dawley rats ( $\sim 170 \mathrm{~g})$ were purchased from Harlan Italy (San Pietro al Natisone,Udine, Italy) and housed under a 12-h light:12-h dark cycle. The animals were acclimated to their environment for 1 week and had ad lib. access to tap water and rodent standard diet. All animal experiments complied with the Italian (D.L. no.116 of January 27, 1992) and associated guidelines in the European Co mmunities Council (Directive of November 24, 1986, 86/609/ECC). All efforts were made to minimize animal suffering, and to reduce the number of animals used. The rats were divided into the three following groups of 6 animals: 1) sham-operated controls (SHAM); 2) ovariectomized animals (OVX); and 3) OVX treated with $\mathrm{E}_{2}\left(\mathrm{OVX}+\mathrm{E}_{2}\right)$. At the onset of the study, OVX rats were bilaterally ovariectomized under anesthesia (ketamine, $100 \mathrm{mg} / \mathrm{kg}$; xylazine, $5 \mathrm{mg} / \mathrm{kg}$ i.p.). The SHAM animals were subjected to the same general surgical procedure as OVX groups, except that the ovaries were not excised. $E_{2}$ treatment $(25 \mu \mathrm{g} / \mathrm{kg}$ s.c. twice a week; Sigma, St. Louis, MO) began 2 days after surgery and continued for 7 weeks. SHAM and OVX rats received vehicle (sterile sesame oil). Last administration was performed $2 \mathrm{~h}$ before sacrifice.

\subsection{Body weight, food intake, and body gain and fat mass}

Throughout the treatment period, body weight and food intake were monitored once a week. At the end of $7^{\text {th }}$ week, food intakes were calculated and expressed as area under the curve obtained plotting the grams of food versus time (average of $\mathrm{g} / 7$ weeks/animal). Before sacrifice, bioelectrical impedance analysis (BIA) was applied to body composition assessment using a BIA 101 analyzer, modified for the rat (Akern, Florence, Italy). Fat-free mass (FFM) was calculated using the bioelectrical impedance analysis $(50 \mathrm{kHz})$ prediction equation of Ilagan et al. [37], and fat mass content was determined as the difference between body weight and fat-free mass. 


\subsection{Tissue collection and serum iron-status parameters}

SHAM rats at random stages of the estrous cycle, $\mathrm{OVX}$, and $\mathrm{E}_{2}$-treated rats were sacrificed at 7 weeks. Blood collected by cardiac puncture was centrifuged at $1500 \times \mathrm{g}$ at $4^{\circ} \mathrm{C}$ for $15 \mathrm{~min}$ and sera were stored at $-80^{\circ} \mathrm{C}$ for later biochemical and hormonal measurements. Iron-status analyses included ferritin, iron, TIBC (Total Iron Binding Capacity) and UIBC (Unsaturated Iron-Binding Capacity), measured by the Roche/Hitachi Modular Analytics P clinical chemistry analyzer (Roche Diagnostics GmbH, Mannheim, Germany), using manufacturer's reagents. Serum $\mathrm{E}_{2}$ was determined by an ELISA kit (Abbott Laboratories, Abbott Park, IL). Peritoneal and subcutaneous white adipose tissues were excised and immediately frozen in liquid nitrogen.

\subsection{Preparation of tissue extracts}

To obtain cytosolic extracts for electrophoretic mobility-shift assay (EMSA) and Western blot analysis tissue samples $(0.3 \mathrm{~g})$ were disrupted by homogenization on ice in lysis buffer $(20 \mathrm{mM}$ Tris-HCl, pH 7.5, 10 mM NaF, 150 mM NaCl, 1 \% Nonidet P-40 (NP-40), 1 mM phenylmethylsulphonyl fluoride, $1 \mathrm{mM} \mathrm{Na}_{3} \mathrm{VO}_{4}$, leupeptin and trypsin inhibitor $10 \mu \mathrm{g} / \mathrm{ml}$ ). After 30 min the supernatant fraction was obtained by centrifugation at $21000 \mathrm{x}$ g for $15 \min$ at $4{ }^{\circ} \mathrm{C}$ and then stored at $-80^{\circ} \mathrm{C}$. Protein concentration was determined by the Bio-Rad protein assay (Bio-Rad, Milan, Italy).

\subsection{Electrophoretic mobility-shift assay (EMSA)}

Plasmid pSPT-fer containing the sequence corresponding to the IRE of the H-chain of human ferritin, linearized at the Bam HI site, was transcribed in vitro as previously described [21, 22]. For RNA-protein band-shift analysis, cytosolic extracts $(5 \mu \mathrm{g})$ were incubated for $30 \mathrm{~min}$ at room temperature with $0.2 \mathrm{ng}$ of in vitro-transcribed ${ }^{32} \mathrm{P}$-labelled IRE RNA. The reaction was performed 
in buffer containing $10 \mathrm{mM}$ HEPES, $\mathrm{pH} 7.5,3 \mathrm{mM} \mathrm{MgCl} 2,40 \mathrm{mM} \mathrm{KCl}, 5 \%$ (v/v) glycerol, $1 \mathrm{mM}$ DTT and $0.07 \%$ (v/v) NP-40, in a final volume of $20 \mu 1$. To recover total IRP1 binding activity, cytosolic extracts were pre-incubated for $10 \mathrm{~min}$ with 2 -mercaptoethanol (2-ME) at a $2 \%(\mathrm{v} / \mathrm{v})$ final concentration, before the addition of ${ }^{32} \mathrm{P}$-labelled IRE RNA. Unbound RNA was digested for 10 min with $1 \mathrm{U}$ RNase $\mathrm{T}_{1}$ (Roche, Mannheim, Germany), and non-specific RNA-protein interactions were displaced by the addition of $5 \mathrm{mg} / \mathrm{ml}$ heparin for $10 \mathrm{~min}$. RNA-protein complexes were separated on $6 \%$ non-denaturing polyacrylamide gel for $2 \mathrm{~h}$ at $200 \mathrm{~V}$. After electrophoresis, the gel was dried and autoradiographed at $-80^{\circ} \mathrm{C}$. IRPs-RNA complexes were then quantified by GS- 800 imaging densitometer (Bio-Rad). The results are expressed as percent of IRP1 binding activity of the control treated with 2-ME (100 \% of IRP1 RNA-binding activity) and are the average \pm S.E.M. values of four independent experiments.

\subsection{Western blot analysis}

Samples containing 50-100 $\mu \mathrm{g}$ of proteins were denatured, separated on a $12 \%$ (for ferritin) or $8 \%$ (for IRP1 and TfR-1) SDS-polyacrylamide gel and electro-transferred onto a nitrocellulose membrane (Amersham Biosciences, Little Chalfont, Buckinghamshire, UK) using a Bio-Rad Transblot (Bio-Rad). Proteins were visualized on the filters by reversibile staining with Ponceau-S solution and destained in PBS. Membranes were blocked at room temperature in milk buffer [1x PBS, $10 \%(\mathrm{w} / \mathrm{v})$ non-fat dry milk, $0.1 \%(\mathrm{v} / \mathrm{v})$ Tween-20] and then incubated at $4^{\circ} \mathrm{C}$ overnight with 1:1 000 rabbit polyclonal antibody to human ferritin cross-reactive with rat protein (Dako Cytomation, Glostrup, Denmark), or with 1:1 000 mouse antibody to human transferrin receptor-1 cross-reactive with rat TfR-1 (Zymed Laboratories Inc., CA, USA), or with 1:250 goat antibody to human IRP1 cross-reactive with rat IRP1 (Santa Cruz Biotechnology, Inc., Santa Cruz, CA, USA). Subsequently, the membranes were incubated for $90 \mathrm{~min}$ at room temperature with peroxidaseconjugated goat anti-mouse $\operatorname{IgG}+\operatorname{IgM}$, or peroxidase-conjugated rabbit anti-goat $\mathrm{IgG}$, or 
peroxidase-conjugated goat anti-rabbit IgG (all the secondary antibodies were purchased from Jackson ImmunoResearch Laboratories, Baltimore Pike, West Grove, PA). The resulting complexes were visualized using chemoluminescence Western blotting detection reagents (ECL, Amersham Biosciences, Little Chalfont, Buckinghamshire, UK). The optical density of the bands was determined by a GS-800 imaging densitometer (Bio-Rad). Normalisation of results was ensured by incubating the nitrocellulose membranes in parallel with the $\beta$-actin antibody (Sigma).

\subsection{Statistical analysis}

All data were presented as mean \pm S.E.M. Statistical analysis was performed by one-way ANOVA test followed by Bonferroni's test. Statistical significance was set at $\mathrm{P}<0.05$. 


\section{Results \\ 3.1. Body weight gain, food intake, and body fat in ovariectomized and $E_{2}$-treated rats}

As evident in table1, ovariectomy leads to a significant increase of body weight, and this change in body weight paralleled to the increase in food intake. Moreover, the change in body weight was related to the variation of fat mass, which was significantly increased in OVX animals. All these modifications were significantly reverted by $\mathrm{E}_{2}$ treatment.

\subsection{Serum parameters}

$\mathrm{E}_{2}$ levels were evaluated in all animal groups to confirm the hypoestrogenism induced by OVX and its level in $\mathrm{E}_{2}$-treated animals. As reported in table 2, after 7 weeks, OVX significantly reduced the $\mathrm{E}_{2}$ level $(\mathrm{P}<0.001)$ and as expected, $\mathrm{E}_{2}$ treatment increased the hormone level as compared to either OVX $(\mathrm{P}<0.001)$ or SHAM $(\mathrm{P}<0.05)$ group.

Moreover, in OVX animals a significant decrease in serum iron was evidenced. This reduction in serum iron level was accompanied with a very significant decrease in TIBC. Conversely, no significant modification of ferritin and UIBC was evidenced in OVX rats. Interestingly, when OVX rats were treated with $\mathrm{E}_{2}(25 \mu \mathrm{g} / \mathrm{kg}$, s.c.), increased iron, ferritin, and TIBC were observed. In $\mathrm{E}_{2}$-treated OVX rats, UIBC value did not significantly change, even though a decreasing trend was observed.

\subsection{IRP1 activity and expression in adipose tissues from ovariectomized and $E_{2}$-treated rats}

As shown in Fig. 1a, ovariectomy caused a remarkable decrease in the RNA-binding activity of IRP1 in peritoneal adipose tissue. A similar regulation of IRP1 activity, albeit with a lesser but 
significant extent, was observed in subcutaneous adipose tissue after ovariectomy (Fig. 2a). In both types of adipose tissue, IRP1 RNA-binding activity was efficiently restored by hormone therapy $\left(\mathrm{E}_{2}\right)$. All samples were incubated with mercaptoethanol (2-ME) to ensure full activation of IRP1. Concerning IRP1 protein expression, Western blot analysis showed an overall decreasing trend in ovariectomized rats, which was more pronounced and significant in subcutaneous adipose tissue (fig. 2b). Differently from IRP1 activity modulation, $E_{2}$ treatment was not able to reverse the decrease of IRP1 expression induced by ovariectomy.

\subsection{Ferritin and TfR-1 expression in adipose tissues from ovariectomized and $E_{2}$-treated rats}

Ovariectomy increased ferritin expression in peritoneal adipose tissue, whereas hormone therapy had no significant effect on OVX rats (fig. 3a). Conversely, no significant variation of ferritin content was observed in subcutaneous adipose tissue of OVX animals, whereas a marked upregulation of protein expression was revealed after $E_{2}$ treatment (fig. 4a).

As depicted in fig. $3 \mathrm{~b}$ and $4 \mathrm{~b}$, TfR-1 expression was significantly lowered by ovariectomy in both peritoneal and subcutaneous adipose tissues, when compared with SHAM animals. In this circumstances, $\mathrm{E}_{2}$ treatment caused an overall increasing trend of TfR-1 expression in OVX animals, which was statistically significant in peritoneal adipose tissue. 


\section{Discussion}

Iron is essential for many biological processes and its deficiency or excess is involved in pathological conditions [1]. A number of studies have reported a correlation between obesity and poor iron status [33-35], although the molecular basis underlying this phenomenon is still obscure. In the present study we have evaluated the binding activity of IRP1 and the expression of ferritin and TfR-1 in adipose tissue from rats having a mild obesity induced by seven-week ovariectomy, a model that mimics estrogen insufficiency [36]. We demonstrate for the first time, to our knowledge, that $\mathrm{E}_{2}$ modulates the RNA binding activity of IRP 1 and affect the ferritin and TfR-1 expression in adipose tissue. Moreover, we observed that ovariectomy induces a significant decrease of serum iron, accompanied with a trend toward a decreased serum ferritin.

Surprisingly, we found that the mild obesity present in ovariectomized rats was associated with a decrease in TIBC, an indirect value of hepatic transferrin synthesis, and that the $\mathrm{E}_{2}$ therapy reverted this effect. The low level of TIBC found in ovariectomized rats is unusual because when serum iron decreases and cellular iron demand is high, the TIBC level usually increases. The atypical scenario that we have found is compatible with a chronic inflammatory condition, in which iron release from cells decreases, lowering the level of TIBC [38], as may occur in certain type of iron deficiency related to inflammation and /or liver disease, two common patho-physiological conditions associated with menopause or ovariectomy [39]. A linkage between $\mathrm{E}_{2}$ serum level and iron metabolism disturbances has been described not only in reference to hypoestrogenism, such as; occurs following ovariectomy or in menopause, but also during pregnancy, a condition in which $\mathrm{E}_{2}$ is elevated [40].

In our study $E_{2}$ treatment increases serum iron and ferritin, showing that these parameters of iron status depend on circulating estrogen levels. Iron deficiency detected in ovariectomized rats could be considered a compensatory mechanism by which the excess of adipose tissue tries to protect itself against the damaging effects of iron-induced oxidative stress. Serum iron decrease in overweight status may be due to larger blood volume and higher basal iron losses associated to 
higher body weight [34]. On the basis of previous findings, the reduction of serum iron level after ovariectomy could also be related to a lower iron uptake. In fact, it was demonstrated that the increase of serum iron in $\mathrm{OVX}$ rats treated with $\mathrm{E}_{2}$ was due to a direct stimulating effect of the hormone in iron by duodenum and its transfer into the blood and liver [27-28].

Evidence suggests that seven-week ovariectomy increases fat mass and leptin serum content in rats, both features of estrogen loss [36]. Leptin might play a role in regulating iron metabolism in overweight status because it shares a number of common biological features with interleukin (IL)-6, a cytokine released in response to inflammation, a condition often associated with obesity [41]. IL-6 induces an increase of hepcidin secretion from liver cells [42], that in turn negatively regulates systemic iron metabolism by directly interacting with ferroportin (FPN1), a protein devoted to control the cellular iron efflux [43]. Therefore, the iron deficiency, that we have found in OVX rats, could be indirectly related to leptin via increasing the expression of hepcidin.

Althoug adipose tissue is considered a non classical target of estrogen stimulation, in vivo and in vitro studies have shown that estrogen is involved in the modulation and distribution of body fat mass [44]. In fact, the increased subcutaneous fat in women develops pubertally, indicating that estrogen may preferentially promote subcutaneous adipose deposition. In contrast, the accretion of abdominal fat in premenopausal women appears to be inhibited by estrogen, whereas men tend to depot abdominal fat [45]. Gender differences in body fat distribution implicate sex steroids in the regulation of adiposity. In particular, both $\mathrm{ER} \alpha$ and $\mathrm{ER} \beta$ are expressed in adipose tissue and evidence for the involvement of ER $\alpha$ in white adipose tissue distribution and in the suppression of fat accumulation and hyperlipidemia was provided by analyzing ER $\alpha$ knockout mice [46]. We previously demonstrated in differentiated 3T3-L1 adipocytes an accumulation of ferritin mRNA with a consequent increased content of $\mathrm{H}$-rich isoferritin that may limit the toxicity of iron in adipose tissue, thus exerting an antioxidant function [35]. In the present study we found that the systemic iron deficiency in ovariectomized rats is linked to an opposite condition in adipose tissue, similar to that observed in iron-rich cells in which ferritin content enhanced and TfR-1 expression 
decreased. In particular, this condition seems to be more effective in peritoneal adipose tissue, where the molecular mechanism governing the post-transcriptional regulation of ferritin and TfR-1 gene expression by estrogen level (OVX and $\mathrm{E}_{2}$ treatment), is based on regulated changes in the IRE binding activity of the IRPs. In fact, in peritoneal adipose tissue of OVX rats the reduced IRP1 binding capacity is consistent with the increase in ferritin expression and the decrease of TfR-1 expression. Furthermore, the recovery of IRP1 binding activity by $\mathrm{E}_{2}$ treatment in ovariectomized rats reinforces the association between post-transcriptional machinery regulation and estrogen levels. . In fact, it has been reported that hormonal signals may regulate post-transcriptionally the synthesis of proteins involved in iron metabolism by affecting IRPs ability to bind to IRE, possibly through induction of signal transduction cascades that result in IRPs phosphorylation [25, 47]. In adipose tissue estrogen may also have rapid, non-genomic biological effects, believed to be mediated through a small fraction of estrogen receptors localized at or near the cell membrane [45]. By these receptors, estrogen could trigger the protein kinase C-dependent phosphorylation of IRP1 which increases its RNA binding activity [8], resulting in an increased TfR-1 expression and in a reduced ferritin content.

A similar profile of IRP1-dependent post-transcriptional regulations occurs also in subcutaneous adipose tissue of OVX animals treated or not with $\mathrm{E}_{2}$, albeit the effect is reproduced to a lesser extent, in particular for ferritin expression.

Indeed, the synthesis of TfR-1 and ferritin is under post-transcriptional as well as transcriptional control [48], so that both mechanisms could be effective in response to environmental changes in iron and/or metabolic signals.

In conclusion, our results suggest that estrogens can functionally regulate the IRE binding activity of the IRP1 and consequently the expression of the ferritin and TfR-1. However, it is difficult to address if iron homeostasis in ovariectomized and $\mathrm{E}_{2}$ treated rats is affected directly by $\mathrm{E}_{2}$ level changes or indirectly by the modifications of peritoneal and subcutaneous fat mass content induced by the hormone, that might have a different iron demand. Further studies are required to support our 
results and to investigate the nature and significance of the relationship among serum and tissue iron parameters, estrogen status and adipose derived hormones.

\section{Acknowledgments}

The authors express their gratitude to Giovanni Esposito and Angelo Russo for animal care and assistance. This study was in part supported by a grant from the Ministero dell'Istruzione, dell'Università e della Ricerca, Italy. 


\section{Disclosure statement:}

GIUSEPPINA MATTACE RASO "no conflicts of interest"

CARLO IRACE "no conflicts of interest"

EMANUELA ESPOSITO "no conflicts of interest"

CARMEN MAFFETTONE "no conflicts of interest"

ANNA IACONO "no conflicts of interest"

ANTONIO DI PASCALE "no conflicts of interest"

RITA SANTAMARIA "no conflicts of interest"

ALFREDO COLONNA "no conflicts of interest"

ROSARIA MELI "no conflicts of interest" 


\section{References}

[1] Fleming RE, Britton RS, Waheed A, Sly WS, Bacon BR. Pathophysiology of hereditary hemochromatosis. Semin Liver Dis 2005;25:411-9.

[2] Dallman PR. Biochemical basis for the manifestations of iron deficiency. Annu. Rev. Nutr 1986; $6: 13-40$.

[3] Cayley WE Jr. Haemochromatosis. BMJ 2008;336:506.

[4] Nelson SK, McCord JM. Iron, oxygen radicals, and disease. Adv Mol Cell Biol 1998; 25:15783.

[5] Harrison PM, Arosio P. The ferritins: molecular properties, iron storage function and cellular regulation. Biochim Biophys Acta 1996;1275:161-203.

[6] Dautry-Varsat A. Receptor-mediated endocytosis: the intracellular journey of transferrin and its receptor. Biochimie 1986;68:375-81.

[7] Pantopoulos K. Iron metabolism and the IRE/IRP regulatory system: an update. Ann N Y Acad Sci 2004;1012:1-13.

[8] Wallander ML, Leibold EA, Eisenstein RS. Molecular control of vertebrate iron homeostasis by iron regulatory proteins. Biochim Biophys Acta 2006;1763:668-89.

[9] Kennedy MC, Mende-Mueller L, Blondin GA and Beinert H. Purification and characterization of cytosolic aconitase from beef liver and its relationship to the iron-responsive element binding protein. Proc Natl Acad Sci USA 1992;89:11730-4.

[10] Guo B, Yu Y, Leibold EA. Iron regulates cytoplasmic levels of a novel iron-responsive element-binding protein without aconitase activity. J Biol Chem 1994;269:24252-60.

[11 ] Guo B, Phillips JD, Yu Y, Leibold EA. Iron regulates intracellular degradation of iron regulatory protein 2 by the proteasome. J Biol Chem 1995; 270:21645-51.

[12] Henderson BR, Kühn LC. Differential modulation of the RNA-binding protein IRP-1 and IRP2 in response to iron. IRP-2 inactivation requires translation of another protein. J Biol Chem 1995;270:20509-15. 
[13] Müllner EW, Neupert B, Kühn LC. A specific mRNA binding factor regulates the irondependent stability of cytoplasmic transferrin receptor mRNA. Cell 1989; 58:373-82.

[14] Aziz N, Munro HN. Iron regulates ferritin mRNA translation through a segment of its 5' untranslated region. Proc Natl Acad Sci USA 1987;84:8478-82.

[15] Hentze MW, Rouault TA, Caughman SW, Dancis A, Harford JB, Klausner RD. A cis-acting element is necessary and sufficient for translational regulation of human ferritin expression in response to iron. Proc Natl Acad Sci USA 1987;84:6730-34.

[16] Eisenstein RS. Iron regulatory proteins and the molecular control of mammalian iron metabolism. Annu Rev Nutr 2000;20:627-62.

[17] Pantopoulos K, Mueller S, Atzberger A, Ansorge W, Stremmel W, Hentze MW. Differences in the regulation of iron regulatory protein-1 (IRP1) by extra- and intra-cellular oxidative stress. J Biol Chem 1997;272:9802-8.

[18] Drapier JC, Hirling H, Wietzerbin J, Kaldy P, Kühn LC. Biosynthesis of nitric oxide activates iron regulatory factor in macrophages. EMBO J 1993;12:3643-49.

[19] Brown NM, Anderson SA, Steffen DW, Carpenter TB, Kennedy MC, Walden WE, Eisenstein RS. Novel role of phosphorylation in Fe-S cluster stability revealed by phosphomimetic mutation at Ser-138 of iron regulatory protein 1. Proc Natl Acad Sci USA 1998;95:15235-40.

[20] Meyron-Holtz EG, Ghosh MC, Rouault TA. Mammalian tissue oxygen levels modulate ironregulatory protein activities in vivo. Science 2004;306:2087-90.

[21] Irace C, Scorziello A, Maffettone C, Pignataro G, Matrone C, Adornetto A, Santamaria R, Annunziato L, Colonna A. Divergent modulation of iron regulatory proteins and ferritin biosynthesis by hypoxia/reoxygenation in neurons and glial cells. J Neurochem 2005;95:1321-31.

[22] Festa M, Colonna A, Pietropaolo C, Ruffo A. Oxalomalate, a competitive inhibitor of aconitase, modulates the RNA-binding activity of iron-regulatory proteins. Biochem J 2000;348:315-20. 
[23] Santamaria R, Irace C, Festa M, Maffettone C, Colonna A. Induction of ferritin expression by oxalomalate. Biochim Biophys Acta 2004;1691:151-9.

[24] Maffettone C, De Martino L, Irace C, Santamaria R, Pagnini U, Iovane G, Colonna A. Expression of iron-related proteins during infection by bovine herpes virus type-1. J Cell Biochem 2008;104:213-23.

[25] Leedman PJ, Stein AR, Chin WW and Rogers JT. Thyroid hormone modulates the interaction between Iron Regulatory Proteins and ferritin mRNA Iron-responsive Element. J Biol Chem 1996;271:12017-23.

[26] Zandman-Goddard G, Shoenfeld Y. Hyperferritinemia in autoimmunity. Isr Med Assoc J 2008;10:83-4.

[27] Haouari M, Alguemi C, Sfaxi A, Hedhili A, Nagati K, Zouaghi H. Effects of oestradiol-17 beta in hematological parameters and iron absorption in ovariectomized rats. Horm Metab Res $1993 ; 25: 327-8$.

[28] Haouari M, Haouari-Oukerro F, Alguemi C, Nagati K, Zouaghi H, Kamoun A. Effects of oestradiol-17 beta on small intestine iron absorption and iron uptake into blood and liver. Horm Metab Res 1994;26:53-4.

[29] Borras M. Hormone dependency of splenic iron stroes in the rat: effect of oestrogens on the recuperation of reserves in ferrodeficient subjects. Lab Anim 1998; 32:290-7.

[30] Kershaw EE and Flier JS. Adipose tissue as an endocrine organ. J Clin Endocrinol Metab 2004;89:2548-56.

[31] Bélanger C, Luu-The V, Dupont P, Tchernof A. Adipose tissue intracrinology: potential importance of local androgen/estrogen metabolism in the regulation of adiposity. Horm Metab Res 2002;34:737-45.

[32] Vega GL. Obesity and the metabolic syndrome. Minerva Endocrinol 2004;29:47-54. 
[33] Yanoff LB, Menzie CM, Denkinger B, Sebring NG, McHugh T, Remaley AT,Yanovski JA. Inflammation and iron deficiency in the hypoferremia of obesity. Int J Obes (Lond) 2007;9:1412-9.

[34] Lecube A, Carrera A, Losada E, Hernandez C, Simo R, Mesa J. Iron deficiency in obese postmenopausal women. Obesity (Silver Spring). 2006;14:1724-30.

[35] Festa M, Ricciardelli G, Mele G, Pietropaolo C, Ruffo A, Colonna A. Overexpression of H ferritin and up-regulation of iron regulatory protein genes during differentiation of 3T3-L1 pre-adipocytes. J Biol Chem 2000;275:36708-12.

[36] Meli R, Pacilio M, Mattace Raso G, Esposito E, Coppola A, Nasti A, Di Carlo C, Nappi C, Di Carlo R. Estrogen and raloxifene modulate leptin and its receptor in hypothalamus and adipose tissue from ovariectomized rats. Endocrinology 2004;145:3115-21.

[37] Ilagan J, Bhutani V, Archer P, Lin PK, Jen KL. Estimation of body composition changes during weight cycling by bioelectrical impedance analysis in rats. J Appl Physiol $1993 ; 74: 2092-8$.

[38] Theurl I, Fritsche G, Ludwiczek S, Garimorth K, Bellmann-Weiler R, Weiss G. The macrophage: a cellular factory at the interphase between iron and immunity for the control of infections. Biometals 2005;18:359-67.

[39] Rogers NH, Perfield JW 2nd, Strissel KJ, Obin MS, Greenberg AS. Reduced energy expenditure and increased inflammation are early events in the development of ovariectomyinduced obesity. Endocrinology. 2009 [Epub ahead of print].

[40] Faure A, Haouari M, Sutter BC. Oestradiol and insulin secretion in the rat: when does oestradiol start stimulating the insulin release? Horm Res. 1987;27:225-30.

[41] Hukshorn CJ, Lindeman JHN, Toet KH, Saris WH, Eilers PH, Westerterp-Plantenga MS, Kooistra T. Leptin and the proinflammatory state associated with human obesity. J Clin Endocrin Metab 2004;89:1773-8. 
[42] Chung B, Matak P, McKie AT, Sharp P. Leptin increases the expression of the iron regulatory hormone hepcidin in HuH7 human hepatoma cells. J Nutr 2007;137:2366-70.

[43] Collins JF, Wessling-Resnick M, Knutson MD. Hepcidin regulation of iron transport. J Nutr 2008;138:2284-8.

[44] Mueller SO, Korach KS. Estrogen receptor and endocrine disease: lessons from estrogen receptor knock out mice. Curr Opin Pharmacol 2001;1:613-9.

[45] Cooke PS and Naaz A. Role of estrogen in adipocytes development and function. Exp Biol Med 2004;229:1127-35.

[46 ] Heine PA, Taylor JA, Iwamoto GA, Lubahn DB, Cooke PS. Increased adipose tissue in male and female estrogen receptor-alphạ knockout mice. Proc Natl Acad Sci USA 2000;97:12729-34.

[47] Thomson AM, Rogers JT, Leedman PJ. Thyrotropin-releasing hormone and epidermal growth factor regulate Iron-Regulatory Protein binding in pituitary cells via protein kinase Cdependent and -independent signaling pathways. J Biol Chem 2000; 275;31609-15.

[48] Ponka P, Beaumont C, Richardson DR. Function and regulation of transferrin and ferritin. Semin Hematol 1998;35:35-54. 


\section{Legends to figures}

Figure 1. a) IRP1 RNA-binding activity in rat peritoneal adipose tissue after ovariectomy (OVX) and hormone therapy $\left(\mathrm{OVX}+\mathrm{E}_{2}\right)$. RNA band-shift assay was performed with $5 \mu \mathrm{g}$ of cytoplasmic proteins and an excess of ${ }^{32} \mathrm{P}$-labelled IRE probe in absence or presence of $2 \%$ 2-ME. RNA-protein complexes were separated on non-denaturing $6 \%$ polyacrylamide gel, revealed by autoradiography and IRP1-RNA complexes were then quantified by densitometric analysis. The results of experiments performed without 2-ME were plotted in a bar graph as percent of the control (SHAM) treated with 2-ME, a condition that reveals total RNA-binding activity of IRP1 (100\%). A representative autoradiogram is shown. b) Western blot analysis showing the effect of ovariectomy $(\mathrm{OVX})$ and the subsequent hormone therapy $\left(\mathrm{OVX}+\mathrm{E}_{2}\right)$ on IRP1 protein levels in cytosolic extracts from rat peritoneal adipose tissue. Equal amounts of proteins were separated on a 8\% SDSpolyacrylamide gel and subjected to Western blot analysis using 1:250 dilution of IRP1 antiserum. After chemoluminescence, the corresponding bands were quantified by densitometric analysis and plotted as relative O.D. in a bar graph. $\beta$-Actin ( $\beta$-act) was used as internal control to standardize the amounts of proteins in each lane. Shown are the means of relative O.D. \pm S.E.M. of all bands plotted in a bar graph compared to sham animals (SHAM). $* * * \mathrm{P}<0.001$ vs SHAM; ${ }^{\circ} \mathrm{P}<0.01$ and ${ }^{\circ 0 \circ} \mathrm{P}<0.001$ vs OVX

Figure 2. a) IRP1 RNA-binding activity in rat subcutaneous adipose tissue after ovariectomy (OVX) and hormone therapy $\left(\mathrm{OVX}+\mathrm{E}_{2}\right)$. EMSA was performed as described in legend of figure 1 . The results of experiments performed without 2-ME were plotted in a bar graph as percent of the control (SHAM) treated with 2-ME and are the average \pm S.E.M. values of all bands. Control treated with 2-ME represents the $100 \%$ of IRP1 RNA-binding activity. A representative autoradiogram is shown. b) Western blot analysis showing the effect of ovariectomy (OVX) and the subsequent hormone therapy $\left(\mathrm{OVX}+\mathrm{E}_{2}\right)$ on IRP1 protein levels in cytosolic extracts from rat subcutaneous 
adipose tissue. The experiments were performed as illustrated in legend of figure 1. Shown are the means of relative O.D. \pm SEM of all bands.

**P $<0.01$ vs SHAM; ${ }^{\circ \circ} \mathrm{P}<0.01$ vs OVX.

Figure 3. Western blot analysis showing the ferritin (Fer) (a) and the transferrin receptor-1 (TfR-1) levels (b) in cytosolic extracts obtained from peritoneal adipose tissue of sham-operated (SHAM), ovariectomized $(\mathrm{OVX})$ and hormone treated $\left(\mathrm{OVX}+\mathrm{E}_{2}\right)$ rats. For ferritin content analysis, equal amounts of cytosolic lysates were fractionated by $12 \%$ SDS-PAGE and subjected to Western blot analysis using 1:1 000 dilution of ferritin antiserum. For TfR-1 content analysis, equal amounts of cytosolic lysates were fractionated by $8 \%$ SDS-PAGE and subjected to Western blot analysis using 1:1 000 dilution of TfR-1 antiserum. The Fer and TfR-1 bands were quantified by densitometric analysis and plotted as relative O.D. in a bar graph. The anti- $\beta$-actin antibody was used to standardize the amounts of proteins in each lane. Shown are the average of the relative O.D. \pm SEM values of all bands.

**P $<0.01$ vs SHAM; ${ }^{\circ} \mathrm{P}<0.01$ vs OVX.

Figure 4. Western blot analysis showing the ferritin (Fer) (a) and the transferrin receptor-1 (TfR-1) levels (b) in cytosolic extracts obtained from subcutaneous adipose tissue of sham-operated (SHAM), ovariectomized (OVX) and hormone treated $\left(\mathrm{OVX}+\mathrm{E}_{2}\right)$ rats. Western blot analysis were performed as described in legend of figure 3. Shown in a bar graph are the average of the relative O.D. \pm SEM values of all bands.

** $\mathrm{P}<0.01$ vs SHAM; ${ }^{\circ 00} \mathrm{P}<0.001$ vs OVX. 
Tab. 1 Changes in body weight, body weight gain, food intake and fat mass in sham operated (SHAM) or ovariectomized rats treated with $\left(\mathrm{OVX}+\mathrm{E}_{2}\right)$ or without $(\mathrm{OVX}) 17 \beta$-estradiol for 7 weeks.

\section{SHAM}

OVX

$\mathbf{O V X}+\mathbf{E}_{2}$

Body weight (g)

$239 \pm 3$

$305 \pm 3^{\mathrm{a}}$

$212 \pm 6^{\mathrm{b}, \mathrm{c}}$

Body weight gain (g)

$74 \pm 3$

$142 \pm 3^{\mathrm{a}}$

$47 \pm 4^{\mathrm{a}, \mathrm{c}}$

Dietary intake

$100.3 \pm 3.5$

$111.5 \pm 1.5^{\mathrm{b}}$

$96.1 \pm 1.9^{\mathrm{c}, \mathrm{d}}$

(g/7 weeks/animal)

Fat mass (g)

$21.7 \pm 1.1$

$35.2 \pm 0.7^{\mathrm{a}}$

$17.6 \pm 0.7^{\mathrm{c}, \mathrm{d}}$

Values are means \pm S.E.M of six animals.

${ }^{\mathrm{a}} \mathrm{P}<0.001$ vs SHAM

${ }^{\mathrm{b}} \mathrm{P}<0.01$ vs SHAM

${ }^{c} \mathrm{P}<0.001$ vs OVX

${ }^{\mathrm{d}} \mathrm{P}<0.05$ vs SHAM 
Tab. 2 Changes in serum parameters in sham operated (SHAM) or ovariectomized rats treated with $\left(\mathrm{OVX}+\mathrm{E}_{2}\right)$ or without $(\mathrm{OVX}) 17 \beta$-estradiol for 7 weeks.

\section{SHAM}

Estradiol $(\mathrm{pg} / \mathrm{ml})$

$\operatorname{Iron}(\mu \mathrm{g} / \mathrm{dl})$

Ferritin (ng/ml)

Transferrin iron binding capacity (TIBC)

Unsaturated iron binding capacity (UIBC) $(\mu \mathrm{g} / \mathrm{dl})$

$26.0 \pm 1.3$

\section{OVX}

$\mathbf{O V X}+\mathbf{E}_{2}$

$4.2 \pm 0.4^{\mathrm{a}}$

$30.6 \pm 1.6^{\mathrm{b}, \mathrm{c}}$

$446.5 \pm 16.8$

$279.8 \pm 38.23^{\mathrm{c}}$

$570.4 \pm 33.7^{\mathrm{b}, \mathrm{a}}$

$140.8 \pm 14.8$

$127.6 \pm 2.5$

$193.0 \pm 19.5^{\mathrm{d}}$

$574.8 \pm 6.8$

$385.4 \pm 14.0^{\mathrm{a}}$

$630.8 \pm 13.6^{\mathrm{b}, \mathrm{c}}$

$128.2 \pm 16.4$

$119.4 \pm 23.5$

$60.4 \pm 21.1$

Values are means \pm S.E.M of five animals.

${ }^{\mathrm{a}} \mathrm{P}<0.001$ vs SHAM

${ }^{\mathrm{b}} \mathrm{P}<0.001$ vs OVX

${ }^{\mathrm{c}} \mathrm{P}<0.05$ vs SHAM

${ }^{\mathrm{d}} \mathrm{P}<0.05$ vs OVX 
a
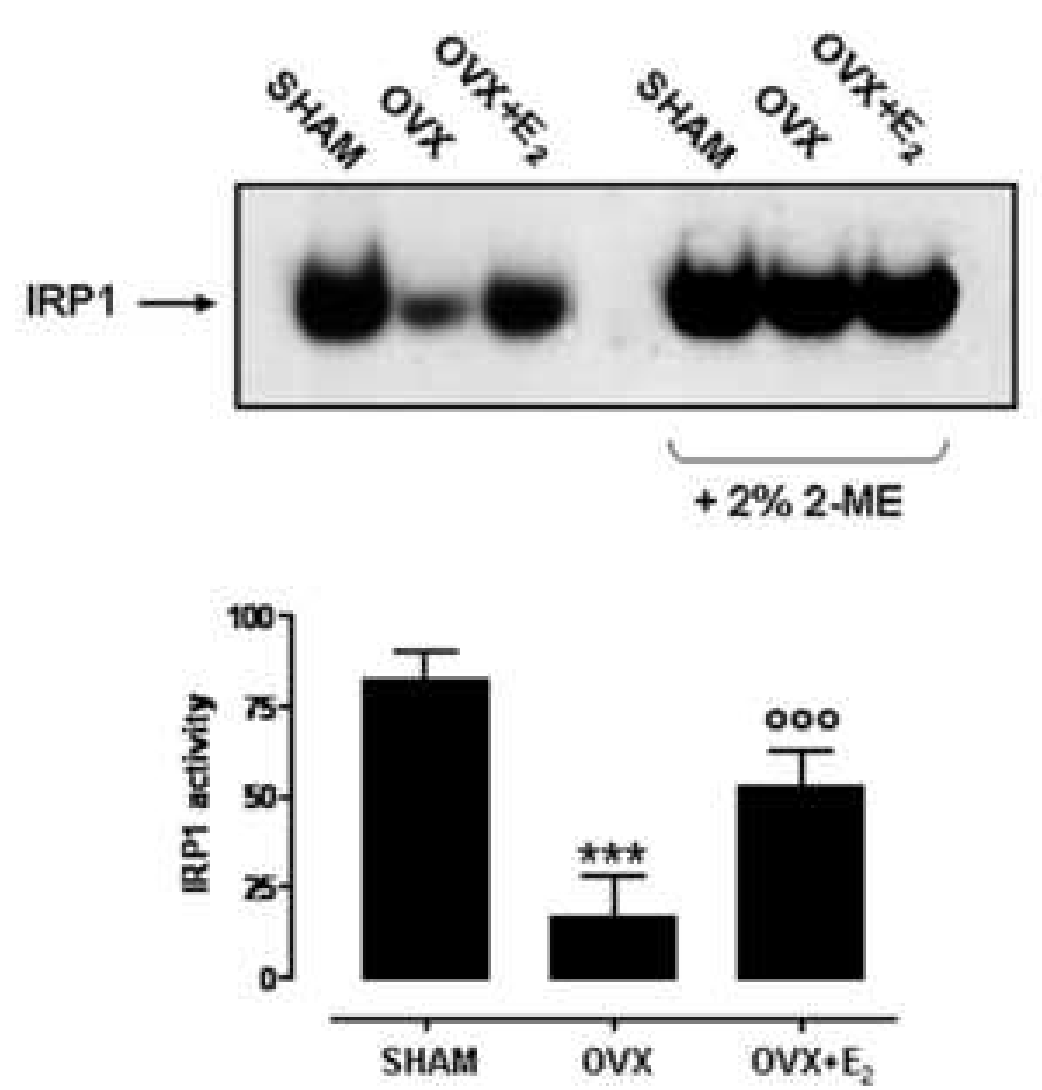

b
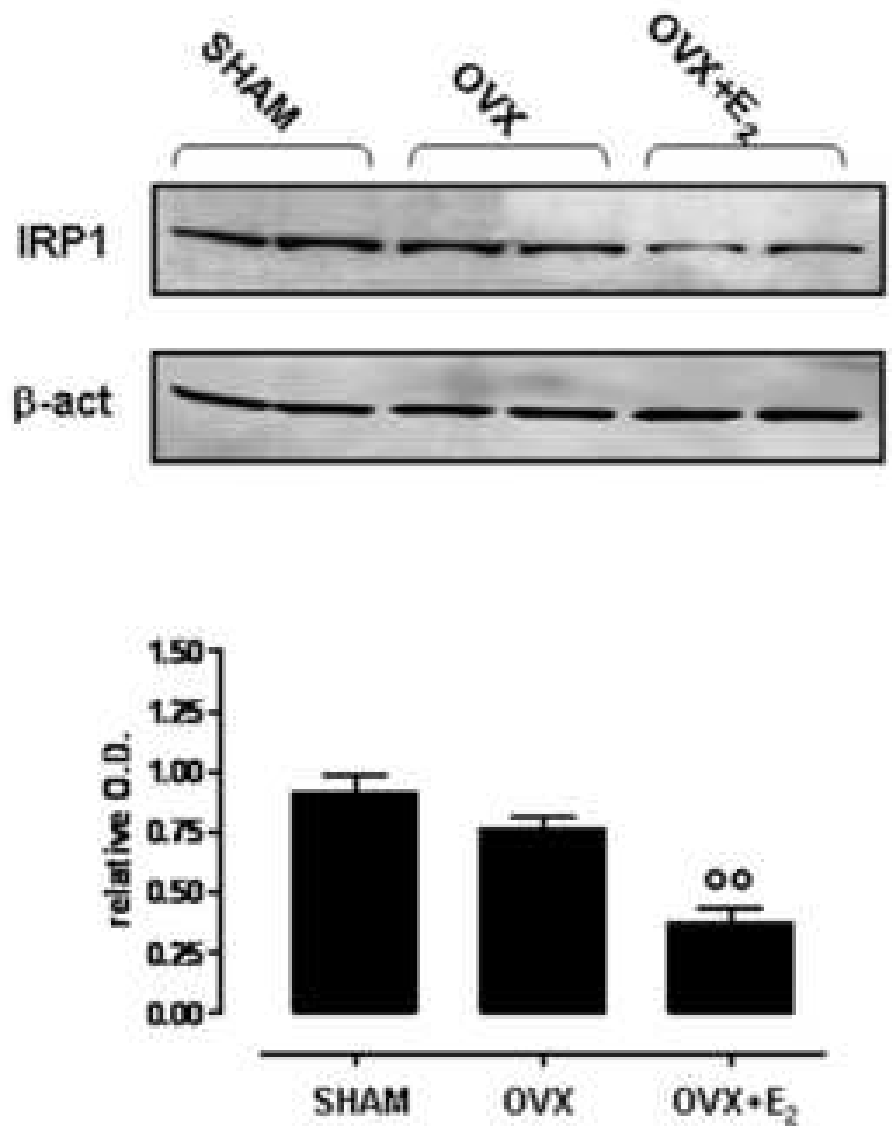
a
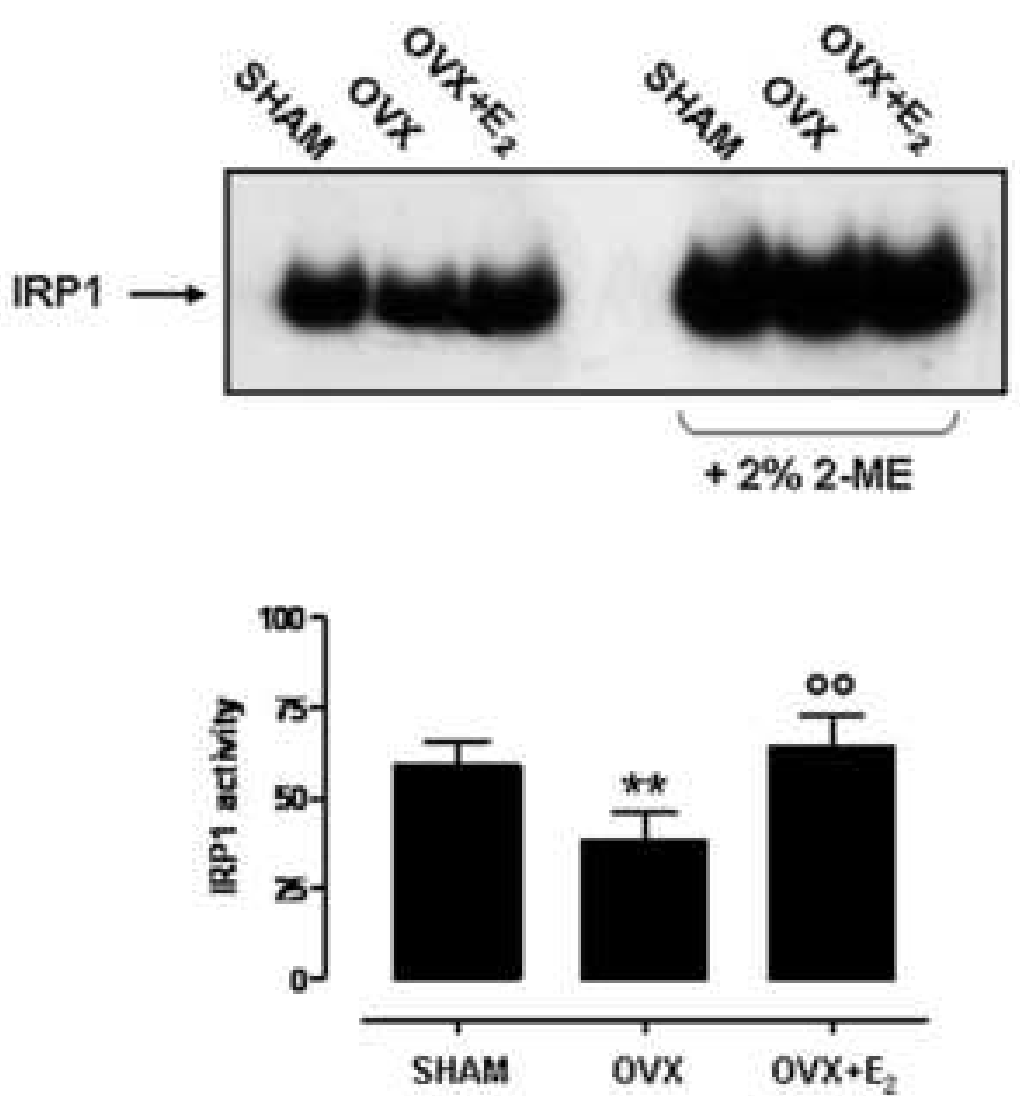

b
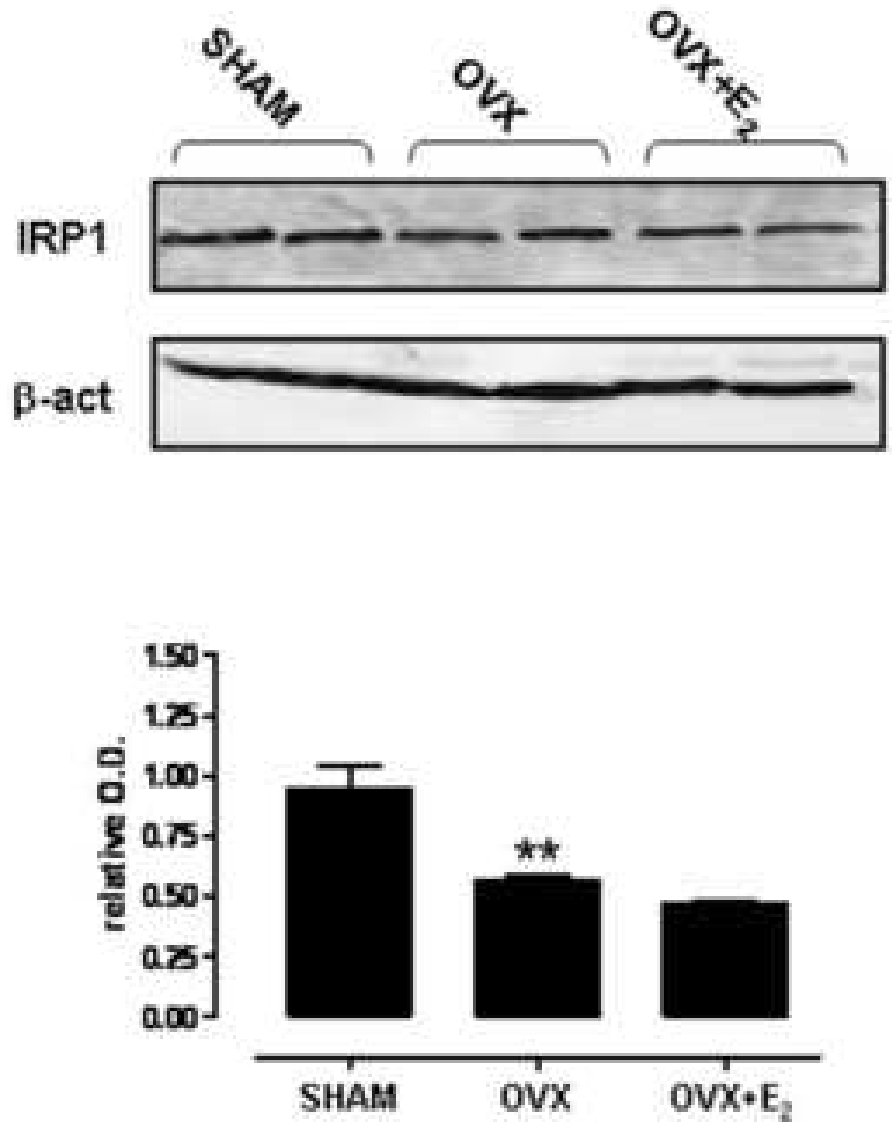
a


b
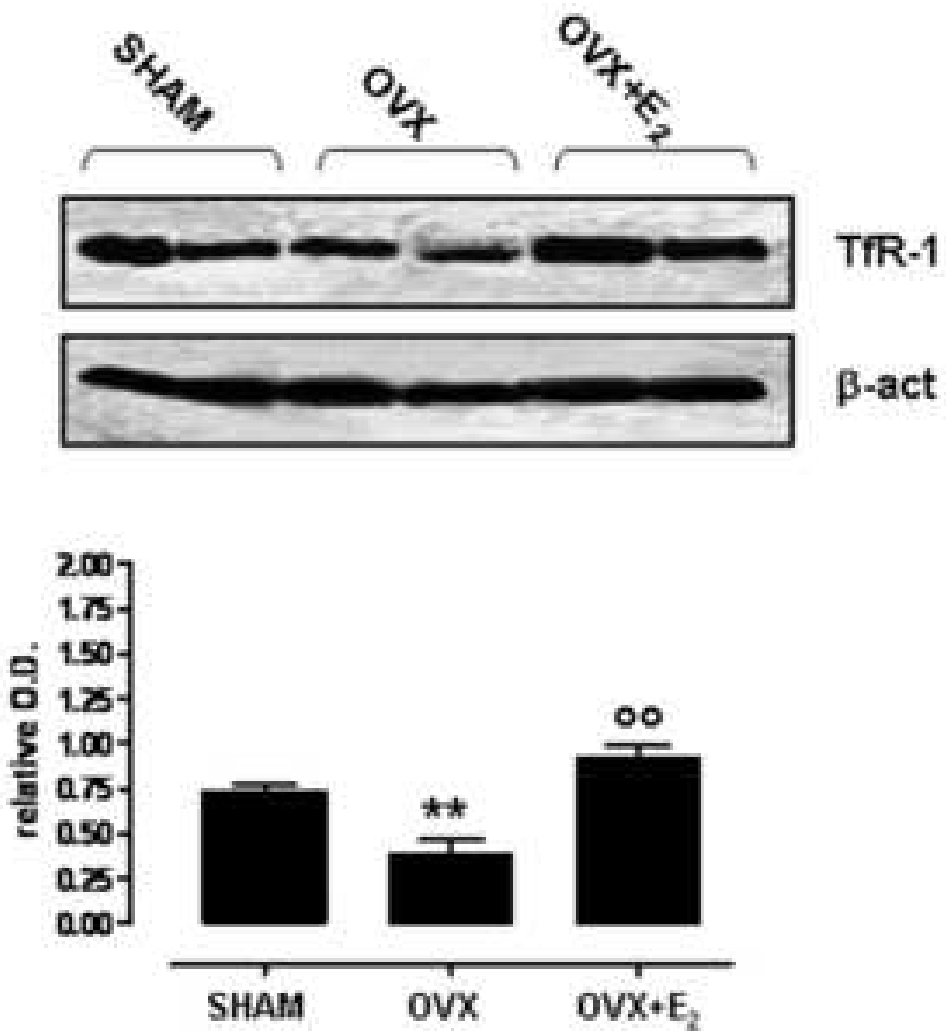
a
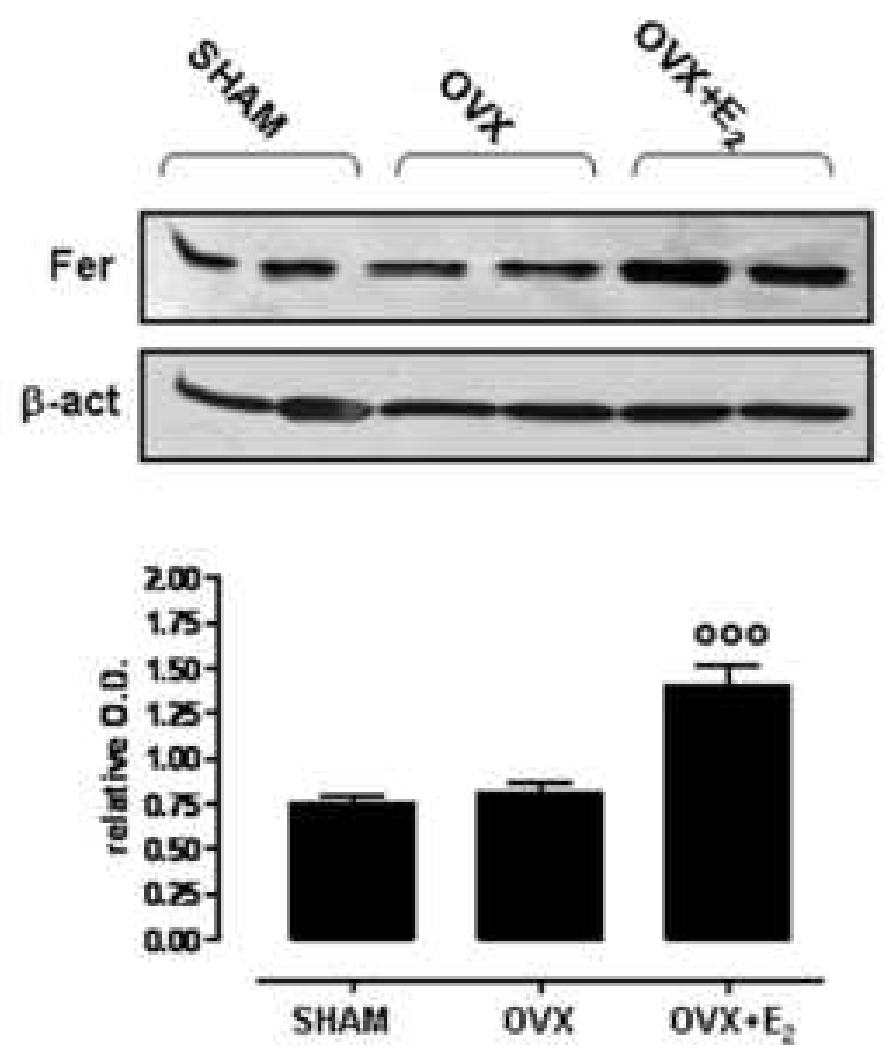

b
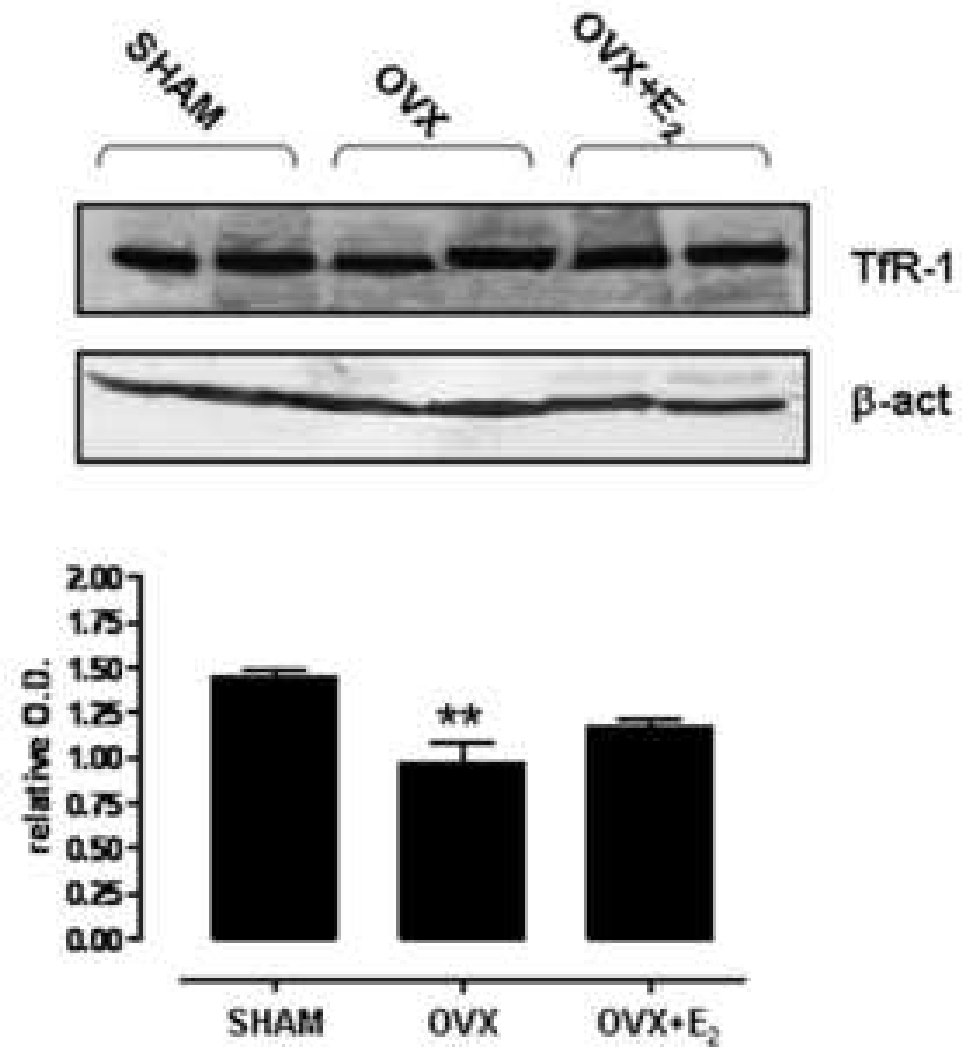